\title{
New record of earthworm Eukerria kuekenthali (Oligochaeta: Ocnerodrilidae) from Sikkim, India
}

\author{
Hem Prasad Subedi* and R. M. Saxena \\ Department of Zoology, D.A.V (PG) College, Dehradun- 248001, INDIA \\ *Corresponding author. E-mail: hem_subedi2003@yahoo.co.in
}

\begin{abstract}
The earthworm genus Eukerria kuekenthali (Michaelsen 1908) is recorded for the first time from the Sikkimese soil. Inter/ intra specific variations have not been observed. Altitude plays a vital role in the distribution pattern of this species. The photographic descriptions with illustrations are provided.
\end{abstract}

Keywords: Eukerria kuekenthali, New record, North Sikkim, Altitude specific

\section{INTRODUCTION}

Sikkim, a portion of biodiversity hotspot in north-east India has been investigated for earthworm diversity by Stephenson (1920), Gates (1972), Julka (1988), Julka and Halder (1977) Soota and Halder $(1977,1981)$ and Halder (2003). An extensive faunistics survey on earthworms of Sikkim $\left(27^{\circ} 5^{\prime} \mathrm{N}\right.$ to $28^{\circ} 9^{\prime} \mathrm{N}$ latitudes and $87^{\circ} 59^{\prime} \mathrm{E}$ to $88^{\circ}$ $56^{\prime}$ E longitudes, in the eastern zone of The Greater Himalayas) has been carried out from February 2008 to March 2009. Study reveals the existence of Eukerria kuekenthali (Michaelsen, 1908), a least described species of earthworm. This species has earlier been reported from Western Ghats, India (Kathireswari and Julka, 2008).

\section{MATERIALS AND METHODS}

Earthworms were collected by digging the soil with shovel or spade. The living worms were dropped in a vessel containing $70 \%$ alcohol. When the worms stop moving they were removed from alcohol and kept in straight position on a piece of blotting paper. Straightened specimen along with the blotting paper are then transferred to flat bottomed container and covered with a thin layer of cotton. 10-15\% formalin is added slowly and kept soaked in it for a period of at least 24 hours. The worms were washed in fresh water and preserved in $70 \%$ alcohol in labelled bottles. The earthworms were examined with the help of dissecting microscope and necessary photographs were taken.

Material examined: 6 non-clitellate, 19 clitellate, Mangan North Sikkim, altitude 1250 m, 27 May 2008., Coll. H.P.Subedi.

Eukerria kuekenthali Michaelsen, 1908

\section{Description (Figs. 1-9)}

Colour red. Length 25-32 mm, diameter $1 \mathrm{~mm}$. Total number of body segments 87-96. Prostomium prolobic type. Setae (lumbricine) eight in number per segment through out the body in four pairs. Clitellum annular extended from $13^{\text {th }}$ segment to $19^{\text {th }}$ segments with a pair of parallel seminal grooves on ventral side (Figs. 1-3). Dorsal pores absent. Spermathecal pore paired minute in intersegmantal furrows of segment 7/8/9 slightly lateral in position (Fig. 4). Male pores paired, minute, in almost straight seminal grooves. Female pores paired, minute, close to anterior region of $14^{\text {th }}$ segments. Genital markings are not prominent.

Septa present in all inter-segmental furrows thin in 4/5-7/ 8 and slightly muscular at inter-segmental furrows of segments $8 / 9-12 / 13$. Gizzard small in $7^{\text {th }}$ segment. Calciferous glands paired, shortly stalked in $9^{\text {th }}$ segment (Figs. 5 and 7). Intestine originate at $12^{\text {th }}$ segment. Last pair of hearts at $11^{\text {th }}$ segment. Testes proandric and male funnels paired, free in $10^{\text {th }}$ segment, seminal vesicles paired in $9^{\text {th }}$ and $11^{\text {th }}$. Prostrate tubular, paired in segment 18 which often extended upto $28-30^{\text {th }}$ segments (Figs. 6 and 9). Penial setae not prominent. Spermatheca adiverticulate, duct about one half times as long as ampulla, slightly, widened before entering into parieties (Fig. 9). Genital marking gland does not seen. Nephridia holonephric type (Fig. 6).

\section{DISCUSSION}

Halder (2003) reported the existence of 18 species from Sikkim and placed under 12 genera and 6 families in which the present species has not been reported. Eukerria kuekenthali for the first time being recorded from the soil of Sikkim. Kathireswari and Julka (2008) have reported this species from the forest ecosystem of Anaikatti Perianaikenpalayam forest range, Tamil Nadu but this study reveals that the present species can also be found in cultivated land, grass land and water flowing from human habitations of Mangan, North Sikkim. Kathireswari and Julka (2008) have reported this species at $1300 \mathrm{~m}$ altitude from Western Ghats but our investigation reveals 


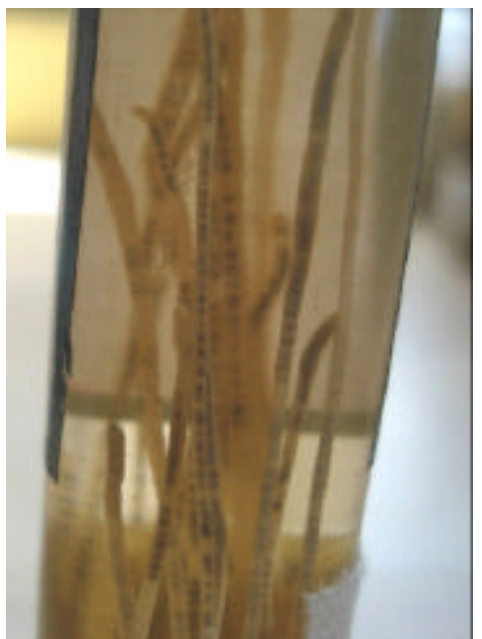

1

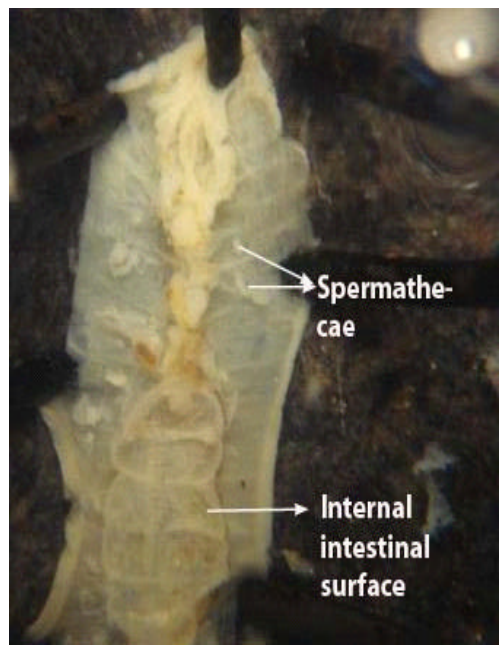

4

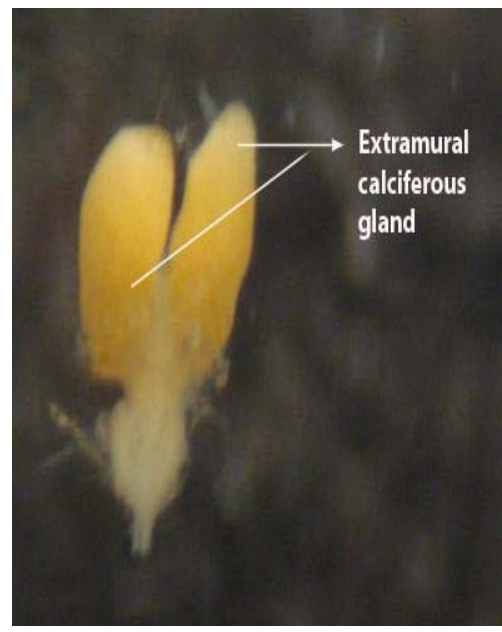

7

Figs.1-9. Eukerria kuekenthali showing 1: Entire body in preservatives, 2: Anterior portion, 3: Genital area, 4: Intestinal surface,

internal, 5: Internal organs, 6: Location of prostate glands and Nephridia, 7: Calciferous gland, 8: Spermatheca, 9: Prostate gland

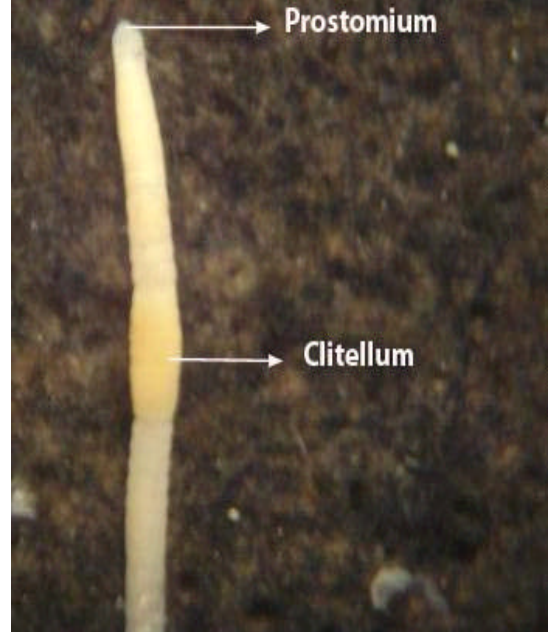

2

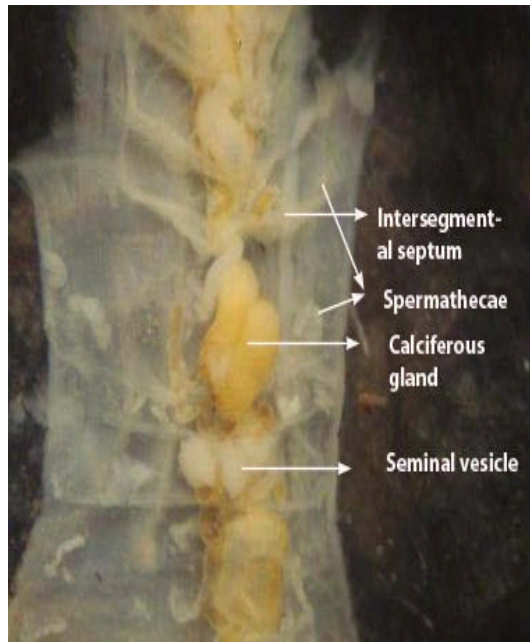

5

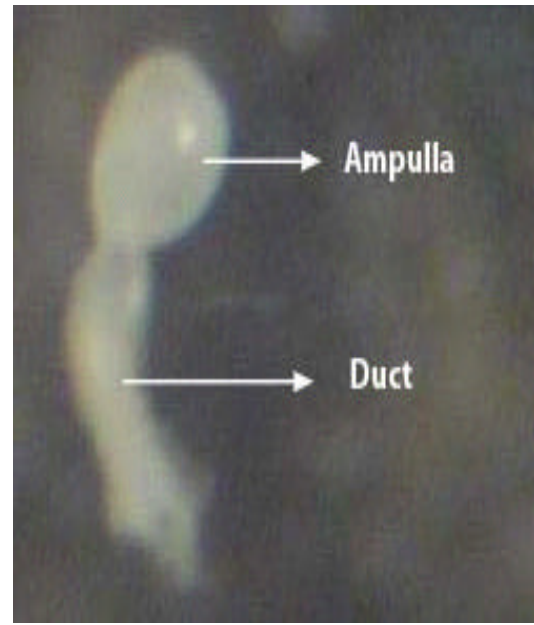

8

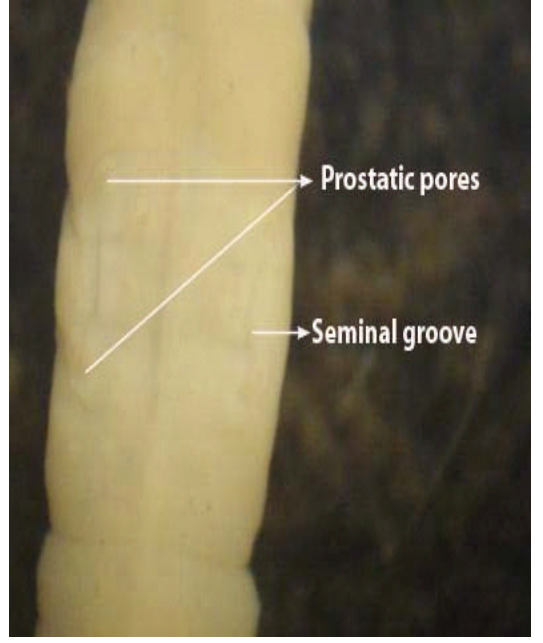

3

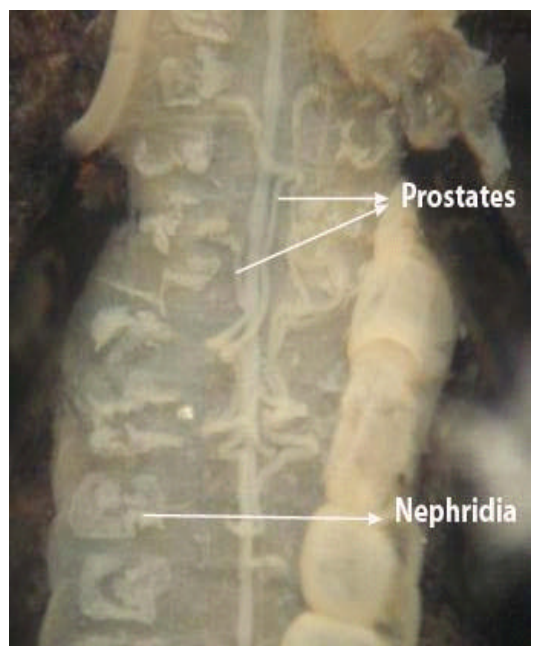

6

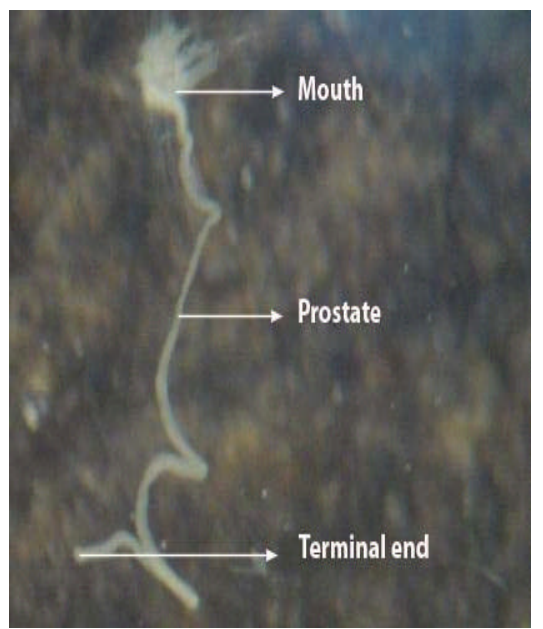

9 
the distribution of this species, ranging from an altitude of 1097-1250m in Sikkim, North East India. It has also been observed that the species is found to be distributed in the equal altitudinal zone in both of the biodiversity hot spot of India. From this, it is substantiated that an altitude plays a vital role in the distribution pattern in some of the genera of earthworms.

\section{ACKNOWLEDGEMENTS}

We are thankful to Dr. J.M. Julka, Solan (HP), India for encouragement and identification of the species. Thanks are due to Dr. R.K.Jauhri, Deptartment of Zoology, D.A.V (PG) College, Dehradun for his help in the preparation of manuscript.

\section{REFERENCES}

Gates, G.S. (1972). Burmese earthworms. An introduction to systematics and biology of megadrile oligochaetes with special reference to Southeast Asia. Trans. Am. Phil. Soc., 62(7): 1-326.
Halder, K.R. (2003). Oligochaeta: Earthworm. State Fauna Series: Fauna of Sikkim, Part., 5: 91-116.

Julka, J.M. (1988). Fauna of India. Megadrile:Oligochaeta(Earthworms):Haplotaxida:Lumbricina: Megascolecoidea:Octochaetidae, Zoological Survey of India, Calcutta.

Julka, J.M. and Halder, K.R. (1977). New records of earthworms (Oligochaeta: Lumbricidae) from Sikkim. Newsl.Zool.Surv. India, 3: 296-297.

Kathireswari, P. and Julka, J.M. (2008). First record of earthworms Perionyx ceylanensis and Eukerria kuekenthali (Annelida: Oligochaeta) from mainland India.Megadrilogica., 12(8): 117-120.

Michaelsen, W. (1908). Die Oligochäten Westindiens. Zoologische Jahrbücher, Abteilung für Systematic, Jena, Suppl., 11: 13-32, 1Taf.

Soota, T.D. and Halder, K.R. (1977). Two species of the genus Amyanthas (Oligochaeta: Megascolecidae) from Sikkim. Newsl. Zool. Surv. India, 3(4): 150-151.

Soota, T.D. and Halder, K.R. (1981). On some earthworms from Eastern Himalayas. Rec. Zool. Surv. India, 79: 231234. 